\title{
Distribution of a Lysosomal Enzyme in the Adult Brain by Axonal Transport and by Cells of the Rostral Migratory Stream
}

\author{
Marco A. Passini, Edward B. Lee, Gregory G. Heuer, and John H. Wolfe \\ Department of Pathobiology and Center for Comparative Medical Genetics, School of Veterinary Medicine, University of \\ Pennsylvania, and Division of Neurology, Children's Hospital of Philadelphia, Philadelphia, Pennsylvania 19104
}

\begin{abstract}
A portion of the lysosomal enzymes produced by cells is secreted, diffuses through extracellular spaces, and can be taken up by distal cells via mannose-6-phosphate receptor-mediated endocytosis. This provides the basis for treating lysosomal storage diseases, many of which affect the CNS. Normal enzyme secreted from a cluster of genetically corrected cells has been shown to reverse storage lesions in a zone of surrounding brain tissue in mouse disease models. However, low levels of enzyme activity and reduction of storage lesions also have been observed at sites in the brain that may not be explained by a contiguous gradient of secreted enzyme diffusing away from the genetically corrected cells. No direct evidence for alternative mechanisms of enzyme transport has been shown, and little is understood about the intracellular movement of lysosomal enzymes in neurons. We investigated whether axonal trans-
\end{abstract}

port could occur, by expressing an eukaryotic lysosomal enzyme that can be visualized in tissue sections ( $\beta$-glucuronidase) in brain structures that have defined axonal connections to other structures. This resulted in the transfer of enzyme to, and a reversal of storage lesions in, neurons that project to the gene expression site, but not in nearby structures that would have been corrected if the effect had been mediated by diffusion. In addition, transduction of cells in the subventricular zone resulted in the uptake of $\beta$-glucuronidase by cells entering the rostral migratory stream. Gene transfer to specific neuronal circuits or cells in migratory pathways may facilitate delivery to the global brain lesions found in these disorders.

Key words: adeno-associated virus; $\beta$-glucuronidase; septohippocampal system; axonal transport; rostral migratory stream; lysosomal storage disease; gene therapy
The lysosomal storage diseases are a family of $\sim 50$ inherited disorders, most of which are caused by mutations in lysosomal acid hydrolase genes (Neufeld, 1991). The loss of these catabolic enzymes results in the accumulation of substrate in cells of the CNS and other organ systems, which eventually leads to lysosome distention and loss of cellular function (Walkley, 1998). In the case of mucopolysaccharidosis type VII (MPS VII), a homozygous null mutation of the $\beta$-glucuronidase (GUSB) gene in mice results in the accumulation of glycosaminoglycans in neurons and glial cells throughout the brain (Birkenmeier et al., 1989; Vogler et al., 1990).

A feature of most lysosomal enzymes is that they are secreted into the extracellular space and taken up by other cells in a receptor-mediated endocytosis process called cross-correction (Neufeld and Fratantoni, 1970; Sando and Neufeld, 1977; Taylor and Wolfe, 1994). This mechanism has been shown in the MPS VII mouse brain to reverse storage lesions in neural cells surrounding a graft of genetically corrected fibroblasts (Taylor and Wolfe, 1997). Direct intraparenchymal brain injections with several types of viral vectors also have been effective (Ghodsi et al., 1998; Skorupa et al., 1999; Stein et al., 1999; Bosch et al., 2000a,b;

Received Feb. 1, 2002; revised April 5, 2002; accepted May 2, 2002.

This study was supported by National Institutes of Health Grants NS38690 and DK42707 (J.H.W.) and by Institute for Human Gene Therapy Vector Core Center Grant DK47747. National Research Service Award training grants supported M.A.P. and G.G.H. (DK07748) and E.B.L. (AG00255); G.G.H. also was supported by a fellowship from the National Institute of Mental Health (MH12285). We thank A. Polesky, M. Parente, S. Gallagher, E. Cabacungan, C. Jones, A. Crystal, G. Gao, and $\mathrm{G}$. Qu for their assistance.

Correspondence should be addressed to Dr. John H. Wolfe, 502G Abramson Research Center, Children's Hospital of Philadelphia, 3516 Civic Center Boulevard, Philadelphia, PA 19104. E-mail: jhwolfe@vet.upenn.edu.

Copyright $(\odot 2002$ Society for Neuroscience $0270-6474 / 02 / 226437-10 \$ 15.00 / 0$
Sferra et al., 2000; Zhu et al., 2000; Consiglio et al., 2001; Frisella et al., 2001). The sphere of enzyme-positive cells found surrounding the injection site is attributable to diff usion, but some types of viruses also can move to distal sites by retrograde axonal transport where they express the transferred gene (Ghodsi et al., 1998; Stein et al., 1999; Zhu et al., 2000). However, the presence of low levels of enzyme activity and some correction of storage in distal sites, including the contralateral hemisphere, have been observed with vectors that transduce cells only at the site of injection (Skorupa et al., 1999; Bosch et al., 2000a,b; Consiglio et al., 2001). This suggests that the enzyme protein itself may be transported. If lysosomal enzymes can be transported within the CNS, transducing selected structures may help to distribute the therapeutic protein to the global lesions typical for these disorders.

In this study we tested whether other modes of enzyme transport occurred besides diffusion, by targeting specific anatomical areas of the mouse brain that contain known axonal connections and migratory pathways. $\beta$-Glucuronidase was used as a model for lysosomal enzymes because single enzyme-positive cells can be detected in tissue sections, allowing for localization of the transported protein (Wolfe and Sands, 1996). We delivered GUSB to the brain with adeno-associated virus serotype 2 (AAV2) because this vector remains confined to the injection site and predominately transduces neurons (Kaplitt et al., 1994; Bartlett et al., 1998; Chamberlin et al., 1998). When the AAV2 vector was injected unilaterally into the hippocampus of GUSB-deficient mice, gene expression was detected only at the site of injection, but cells were strongly positive for GUSB activity in both hemispheres of the hippocampus and in the septum. Only regions with axonal connections to the site of transduction were enzyme positive. Moreover, the storage lesions in the distal structures were 
reversed. This indicated that, after the enzyme was transported along the axon, it entered the lysosomal compartment where it was enzymatically active and reversed the pathologic lesion. Furthermore, injection of the vector into the subventricular zone (SVZ) resulted in delivery of GUSB to the olfactory bulb by cells migrating in the rostral migratory stream. Both modes of transport occurred for at least 18 months, which was attributable to the ability of the mammalian housekeeping promoter in the viral vector to sustain expression over time.

\section{MATERIALS AND METHODS}

Animals. Normal $\mathrm{C} 3 \mathrm{H} / \mathrm{HeOuJ}$ mice were purchased from Jackson Laboratory (Bar Harbor, ME) and maintained in our breeding colony. MPS VII mice were produced by heterozygote matings of $\mathrm{C} 57 \mathrm{BL} / 6-\mathrm{By} \mathrm{Bir}-\mathrm{H}$ $2^{\text {bml }}$ gus $^{m p s}$ (Birkenmeier et al., 1989). Identification of affected mice, which contain a single base pair deletion in exon 10 of the GUSB gene, was verified by PCR (Sands and Birkenmeier, 1993; Wolfe and Sands, 1996). All treatments of mice were approved by and performed according to the guidelines of the Institutional Animal Care and Use Committee.

$A A V 2$ vectors. The detailed construction of the AAV2 vectors that were used in this study has been reported previously (Skorupa et al., 1999; Passini and Wolfe, 2001). AAV2 constructs containing either the $378 \mathrm{bp}$ human GUSB promoter (Shipley et al., 1991; Wolfe et al., 1995) or the human cytomegalovirus immediate-early (CMV) promoter were cloned upstream of the human GUSB cDNA (Oshima et al., 1987; Miller et al., 1990) and packaged by the Institute for Human Gene Therapy Vector Core (see Fisher et al., 1997) into AAV2-H $\beta$ H and AAV2-CV $\beta$, respectively. Brains were injected at equal titers of $4.5 \times 10^{12}$ genome equivalents $/ \mathrm{ml}$.

Stereotaxic injections into adult mice. Adult normal and mutant mice (10-12 weeks old) were injected in the intraperitoneal cavity with an anesthesia dose of $100 \mathrm{mg} / \mathrm{kg}$ ketamine and $5 \mathrm{mg} / \mathrm{kg}$ xylazine. After we placed the mice in a stereotaxic frame, their skulls were drilled, followed by the lowering of a 30-gauge Hamilton syringe into the appropriate brain structure. One microliter of either AAV2-H $\beta$ H or AAV2-CV $\beta$ was injected unilaterally into the appropriate structure over a 5 min period. The stereotaxic coordinates for each brain structure (Franklin and Paxinos, 1997) are written as follows: first coordinate, distance from the bregma line; second coordinate, distance left of the midline; third coordinate, distance ventral to the pial surface. These include the external capsule and surrounding gray matter $(0.00,2.50,1.75 \mathrm{~mm})$, motor cortex $(1.50$ rostral of bregma, $1.50,1.00 \mathrm{~mm})$, somatosensory cortex $(0.50$ caudal of bregma, $2.50,1.00 \mathrm{~mm})$, striatum $(0.00,2.00,3.00 \mathrm{~mm})$, subventricular zone (1.00 rostral of bregma, $1.25,2.00 \mathrm{~mm})$, and ventral hippocampus (2.00 caudal of bregma, $1.50,2.00 \mathrm{~mm}$ ).

Brain preparation. Mice to be killed were anesthetized deeply and perfused transcardially with $1 \times$ PBS, followed by ice-cold fixative $(4 \%$ paraformaldehyde/0.1 M phosphate buffer, $\mathrm{pH}$ 7.4). Brains were dissected out of the skulls, drop-fixed overnight at $4^{\circ} \mathrm{C}$, cryoprotected overnight in $30 \%$ sucrose $/ 0.1 \mathrm{~m}$ phosphate buffer at $4^{\circ} \mathrm{C}$, transferred to plastic molds containing $100 \%$ optimal cutting temperature (OCT) solution, frozen over dry ice, and stored at $-80^{\circ} \mathrm{C}$. On the day before cryosectioning the frozen blocks of brain were placed at $-20^{\circ} \mathrm{C}$ to equilibrate to the cutting temperature. Coronal serial sections were cut at $20 \mu \mathrm{m}$ thickness at $-20^{\circ} \mathrm{C}$. Brain sections designated for enzyme histochemistry were stored at $-20^{\circ} \mathrm{C}$, and those designated for in situ hybridization were stored at $-80^{\circ} \mathrm{C}$.

In situ hybridization. The riboprobes and conditions that were used to detect the virally encoded human GUSB mRNA were described in a recent report (Passini and Wolfe, 2001), which was based on an in situ hybridization protocol published by Barthel and Raymond (2000).

Enzyme histochemistry. Frozen tissue sections were assayed for enzymatic activity with a naphthol-AS-BI- $\beta$-D-glucuronide substrate as reported previously (Wolfe and Sands, 1996). Endogenous GUSB protein was heat inactivated as described to ensure that the positive cells reported in this study were from the viral vectors, because human GUSB is not inactivated at $65^{\circ} \mathrm{C}$ (Frankel et al., 1977; Casal and Wolfe, 2001; Serguera et al., 2001).

Histology. Uninjected and injected MPS VII brains were analyzed for lysosomal storage vacuoles as reported previously (Skorupa et al., 1999). In brief, affected mice were perfused with $4 \%$ paraformaldehyde, and brains were removed and sliced into $500 \mu \mathrm{m}$ coronal slabs with a tissue slicer (Snyder et al., 1995). Tissue slabs were embedded in JB4 resin,

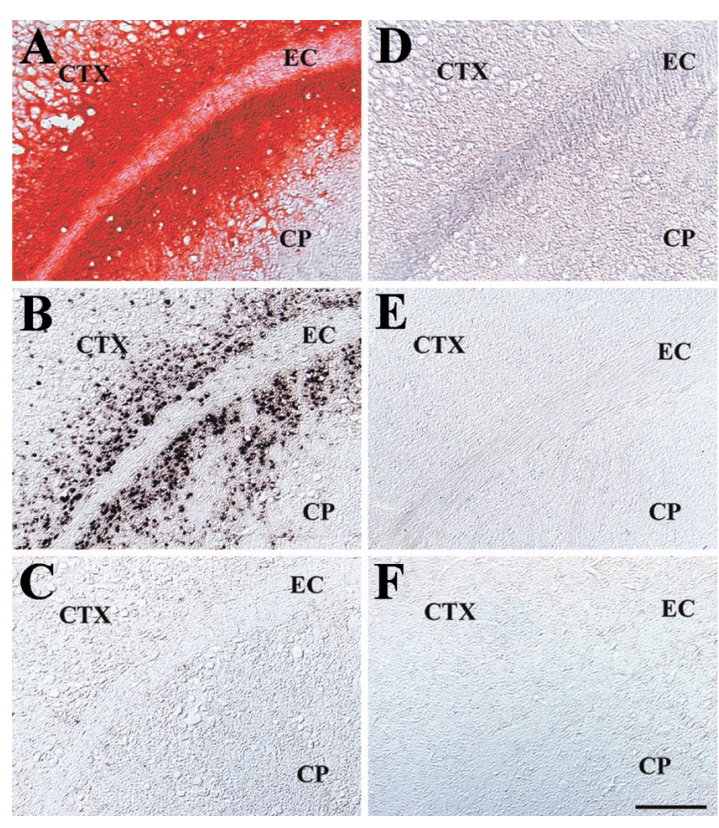

Figure 1. Comparison of AAV2-H $\beta \mathrm{H}$-injected $(A-C)$ and AAV2- $\mathrm{H} \beta \mathrm{H}$ uninjected $(D-F)$ brains in the $\mathrm{C} 3 \mathrm{H} / \mathrm{HeOuJ}$ mouse strain. Enzyme histochemistry $(A, D)$ and in situ hybridization with the antisense riboprobe (ISH-antisense; $B, E$ ) detected many positive cells at 1 month PI, but did not detect positive cells in age-matched uninjected brains. In situ hybridization with the sense riboprobe (negative control) produced little positive signal in the injected brain $(C)$ and no positive signal in the uninjected brain $(F)$. $C P$, Caudate putamen; $C T X$, somatosensory cortex; $E C$, external capsule. Scale bar, $200 \mu \mathrm{m}$.

sectioned at $1 \mu \mathrm{m}$, and stained with $5 \%$ toluidine blue (Wolfe and Sands, 1996).

\section{RESULTS}

\section{Correlation of vector gene expression and enzymatic activity}

For distribution studies the $\mathrm{C} 3 \mathrm{H} / \mathrm{HeOuJ}$ mouse strain was used because it has very low levels of GUSB activity in the brain, and the mouse GUSB protein can be heat inactivated relative to the human protein (Johnson et al., 1986; Gallagher et al., 1987; Moullier et al., 1993; Casal and Wolfe, 2001). To show that the results described herein were from exogenous GUSB, we injected normal adult mice with the AAV2-H $\beta \mathrm{H}$ vector into the external capsule and surrounding gray matter and compared them with uninjected age-matched mice. In injected mice (Fig. $1 A-C$ ) the vector-encoded enzyme was detected in the somatosensory cortex, caudate putamen, and external capsule. A large number of transduced cells were found in the somatosensory cortex and caudate putamen, whereas only a low number of transduced cells were detected in the external capsule. The selective transduction of gray matter structures compared with white matter tracts is consistent with AAV2 to infect neurons preferably over glial cells (Bartlett et al., 1998). The larger number of enzyme-positive cells relative to the in situ hybridization-positive cells was attributable to local cross-correction. In uninjected mice (Fig. 1D-F) the corresponding structures were negative for both enzyme histochemistry and in situ hybridization. The lack of detection of endogenous GUSB under the conditions that were used was verified for all brain structures in the following experiments (data not shown), demonstrating that the positive signals reported in this study were from the transferred cDNA. 


\section{Axonal transport of GUSB in the hippocampus}

To test whether GUSB can undergo axonal transport, we used AAV2 to transfer human GUSB into the ventral hippocampus, defined in this study as the cornu ammonis area 3 (CA3) and the dentate gyrus, because the axons projecting into and from this region have well defined, predictable connections. Having a promoter capable of supporting AAV2-mediated gene expression is critical to this investigation. However, a feature of AAV2 vectors is that the duration of transferred gene expression varies in different structures of the adult brain (McCown et al., 1996; Skorupa et al., 1999; Klein et al., 2000; Xu et al., 2001). The human GUSB promoter may circumvent this temporal restriction because of the housekeeping properties of this regulatory element (Kyle et al., 1990; Shipley et al., 1991).

The AAV2 vectors encoding the human GUSB cDNA, one containing the human GUSB promoter (AAV2-H $\beta \mathrm{H})$ and the other containing the CMV promoter $(\mathrm{AAV} 2-\mathrm{CV} \beta)$, were each injected into groups of adult mice in one hemisphere of the ventral hippocampus and were analyzed 1 and 3 months later $(n=3$ for each vector at each time point). The resultant data were reproducible in all mice at all time points.

Transduction with both vectors occurred in the CA3 pyramidal cell layer and in the granule cell layer (GCL) and hilus of the dentate gyrus at 1 month postinjection (PI) (Fig. 2A,B). Enzymepositive cells were detected in a pattern that approximated the transduction pattern (Fig. 2D,E). Neither AAV2 vector spread to the contralateral side (Fig. 2C). However, unlike viral vector gene expression, GUSB enzymatic activity was present in the contralateral side, as demonstrated by a band of red stain in the innermost molecular layer of the dentate gyrus, which wrapped around the circumference of the GCL (Fig. $2 F$ ). This enzyme pattern suggested a mode of transport alternative to diff usion, because a gradient of enzyme-positive cells that extended throughout the contralateral hemisphere would have been expected to be present if this were the case.

By 3 months PI a difference in the expression pattern was apparent. Only a low number of transduced cells were still detectable from the AAV2-CV $\beta$ vector (Fig. $2 G$ ), and the number of enzyme-positive cells was less than that at 1 month (Fig. 2D,J). In contrast, with the AAV2-H $\beta \mathrm{H}$ vector similar numbers of in situ hybridization-positive cells were present at 1 and 3 months (Fig. $2 B, H)$. Although transduced cells were restricted to the ventral hippocampus, abundant enzyme-positive cells were found in the oriens, pyramidal, and radiatum layers of all three CA fields (CA1-CA3) and in the GCL, hilus, and molecular layers of the dentate gyrus at 3 months (Fig. $2 K, M$ ). AAV2-H $\beta$ H vector gene expression was not detected in the contralateral hippocampus at 3 months (Fig. 2I). Nevertheless, a substantial increase in the number of enzyme-positive cells was seen throughout the contralateral hippocampus (Fig. $2 L, M$ ).

For axonal transport of GUSB to the contralateral hemisphere to occur, it is predicted that enzyme would be present in the hippocampal commissure, a structure that is composed of hippocampal axons projecting from opposite hemispheres. This was shown to be true at 3 months PI, in which the hippocampal commissure was positive for GUSB enzyme but negative for GUSB mRNA (Fig. $3 A-C$ ). The majority of enzyme activity stain produced a linear pattern that was localized precisely to the bundle of axons that connect the hippocampal formations from the two sides of the brain. Another nearby white matter tract, the overlying corpus callosum, which does not contribute to the intrahippocampal circuitry, did not show this pattern of staining. There was additional staining detected in a small number of cell bodies in the region, which may be glial cells. Although it is unknown how these cell bodies acquired enzyme, cell-to-cell contact has been shown to transport GUSB between cells (Olsen et al., 1981). Thus contact between neuronal axons and glial cells may be an explanation.

The ability of the human GUSB promoter to support long-term expression was demonstrated in the ventral hippocampus at 18 months PI (Fig. 3D-F). The maintenance of expression resulted in very high levels of enzymatic activity, as illustrated by the blackened staining pattern at the injection site, which can occur in the presence of supraphysiologic levels of GUSB activity (Fig. $3 G)$. The spread of GUSB to the contralateral hemisphere increased at 18 months, which was particularly evident in cells of the oriens and radiatum layers of CA1-CA3 (Fig. 3H). The increased areas of enzyme-positive staining in the contralateral hemisphere correlated with increased GUSB staining in the hippocampal commissure at 18 months (Fig. 3I). Consistent with earlier time points, vector-encoded mRNA was not observed in the contralateral hemisphere or hippocampal commissure at 18 months (data not shown).

\section{Reversal of pathology by axonal transport}

The extensive amount of lysosomal storage in the MPS VII hippocampus (Levy et al., 1996; Casal and Wolfe, 1998) is ideal for determining the therapeutic efficacy of axonal transport. Correction of storage was tested with AAV2- $\mathrm{H} \beta \mathrm{H}$, because the human GUSB promoter was clearly superior to CMV. Three months was chosen to take full advantage of the robust enzymatic activity that accumulated in the both hemispheres. After unilateral injection of the MPS VII ventral hippocampus, storage was reversed in neurons and glial cells in both hemispheres of the CA3 field and the dentate gyrus (Fig. 4).

Axonal transport would be beneficial in treating the global lesions of storage if lysosomal enzymes could become distributed via inter-regional systems. The potential for inter-regional axonal transport was seen in the nigrostriatal system. Injection of AAV2$\mathrm{H} \beta \mathrm{H}$ into the striatum resulted in a high number of transduced cells and a large area of enzyme-positive cells in this structure (Fig. 5A,B). Enzyme-positive cells were detected in the substantia nigra from the striatal injections, but none of these cells was positive for gene expression (Fig. $5 C, D$ ). This pattern is consistent with GUSB distribution by retrograde transport in neurons of the substantia nigra, which send extensive inputs into the striatum (Kordower et al., 2000; Peltekian et al., 2002).

We took advantage of the well defined connections between the ventral hippocampus and the septum to investigate GUSB movement and reversal of pathology within the septohippocampal system. Unilateral injection of the ventral hippocampus with AAV2- $\mathrm{H} \beta \mathrm{H}$ resulted in numerous enzyme-positive cells in discrete regions of the septum at 3 and 18 months PI (Fig. 5F,G). Positive cells were restricted to the medial septal nucleus and to both dorsal septal nuclei. The lack of detectable enzyme-positive cells at 1 month in the septum (Fig. $5 E$ ), followed by detectable levels at 3 and 18 months, is consistent with the temporal pattern of GUSB in the contralateral hippocampus and hippocampal commissure. Transduced cells expressing mRNA were not detected in the septum at any time point (Fig. $5 H$ ).

Unilateral injections of AAV2-H $\beta \mathrm{H}$ into the MPS VII ventral hippocampus resulted in the reversal of pathology in the neuronal and glial cell populations of the medial and both lateral septal 

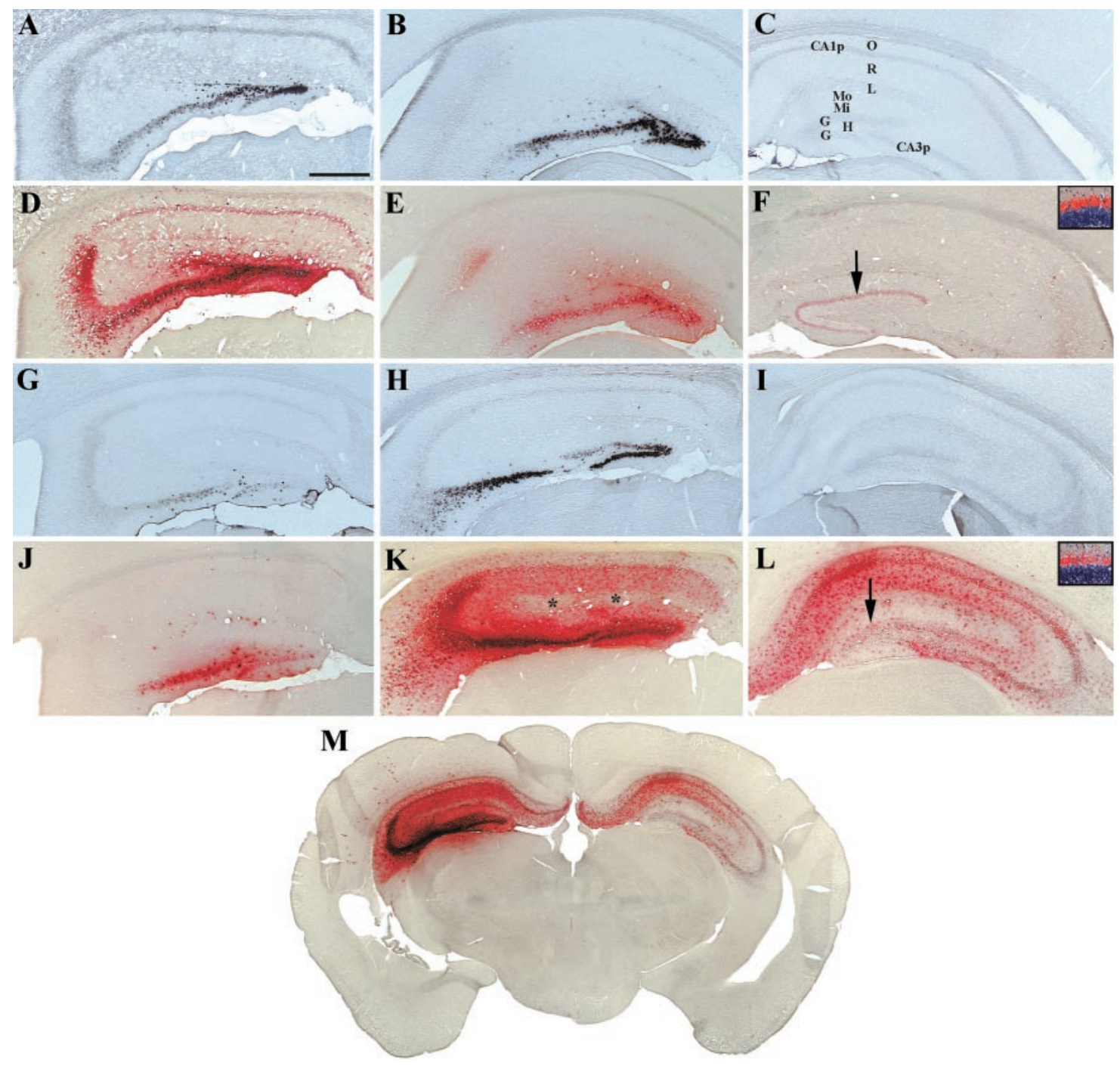

Figure 2. Comparison between AAV2-CV $\beta$ and AAV2-H $\beta \mathrm{H}$ in the hippocampus at 1 month PI $(A-F)$ and 3 months PI $(G-M)$. Shown are ISH-antisense $(A-C, G-I)$ and enzyme histochemistry $(D-F, J-M)$. The number of mRNA- and enzyme-positive cells decreased between 1 month PI $(A, D)$ and 3 months PI $(G, J)$ with AAV2-CV $\beta$. In contrast, the number of cells expressing GUSB mRNA did not change between 1 month $(B)$ and 3 months $(H)$ with AAV2-H $\beta \mathrm{H}$. In addition, a substantial increase in the number of enzyme-positive cells was detected at 3 months $(K)$ compared with 1 month $(E)$ with AAV2-H $\beta \mathrm{H}$. Enzyme-positive cells were clearly present in regions of the ipsilateral hippocampus that were negative for gene expression $(K)$. There was a conspicuous absence of enzyme staining in the CA1-CA3 lacunosum moleculare layers at 3 months (asterisk in $K$ ). The number of enzyme-positive cells in the contralateral hemisphere was also greater at 3 months $(L)$ compared with 1 month $(F)$ with AAV2-H $\beta$ H. At 1 month the enzyme-positive cells were restricted to the inner molecular layer of the dentate gyrus $(F$, arrow). This was verified by the staining of an enzyme-positive section with $0.1 \%$ cresyl violet, which labeled the dentate granule cell layer, but not the dentate molecular layer (small box, $F$ ). At 3 months the pattern of enzyme-positive cells extended to include other regions in the contralateral hippocampus, particularly the oriens and radiatum layers of CA1-CA3 $(L)$. A high-magnification image of a cresyl violet-stained section demonstrated that enzymatic activity was maintained in the inner molecular layer of the dentate gyrus (small box, L). Transduced cells were not detected in the uninjected hemisphere at either time point with AAV2- $\mathrm{H} \beta \mathrm{H}$-injected brains $(C, I)$. An entire brain section at 3 months PI demonstrated how well enzymatic activity was confined to the hippocampus, although a small number of positive cells could be seen in the overlying cortex $(M)$. $C A 1 p$, CA1 pyramidal cell layer; $C A 3 p$, CA3 pyramidal cell layer; $G$, upper and lower blades of the dentate granule cell layer; $H$, hilus; $L$, stratum lacunosum moleculare; $M i$, inner molecular layer of the dentate gyrus; $M o$, outer molecular layer of the dentate gyrus; $O$, stratum oriens; $R$, stratum radiatum. Scale bars: $A-L, 500 \mu \mathrm{m} ; M, 1000 \mu \mathrm{m}$.

nuclei at 3 months (Fig. $6 A-D$ ). However, storage vacuoles were present in structures that were in relatively close proximity to the hippocampus and septum, such as the neocortex, piriform cortex, caudate putamen, and thalamus (Fig. $6 E-H$ ). This suggests that axonal transport was responsible for the clearance of storage in the contralateral hippocampus and septum, because nearby structures also would have been corrected if diffusion had occurred.

\section{GUSB transport by migratory cells}

We also determined that another mode of GUSB transport exists in the adult brain. Injection of the viral vector into the SVZ resulted in GUSB delivery to the olfactory bulb by migrating cells. Stem cells occupying the anterior SVZ undergo tangential migration to the olfactory bulb via the rostral migratory stream, a developmental process that continues in the adult (Altman, 1969). On reaching the subependymal zone of the olfactory bulb, these cells undergo radial migration to specific laminar layers occupied by granule and periglomerular cells (Luskin, 1993; Lois and Alvarez-Buylla, 1994; Uchida et al., 2000).

Unilateral injection of AAV2-H $\beta \mathrm{H}$ into the vicinity of the SVZ resulted in transduction at 1 month PI (Fig. $7 A, D$ ). A coronal 

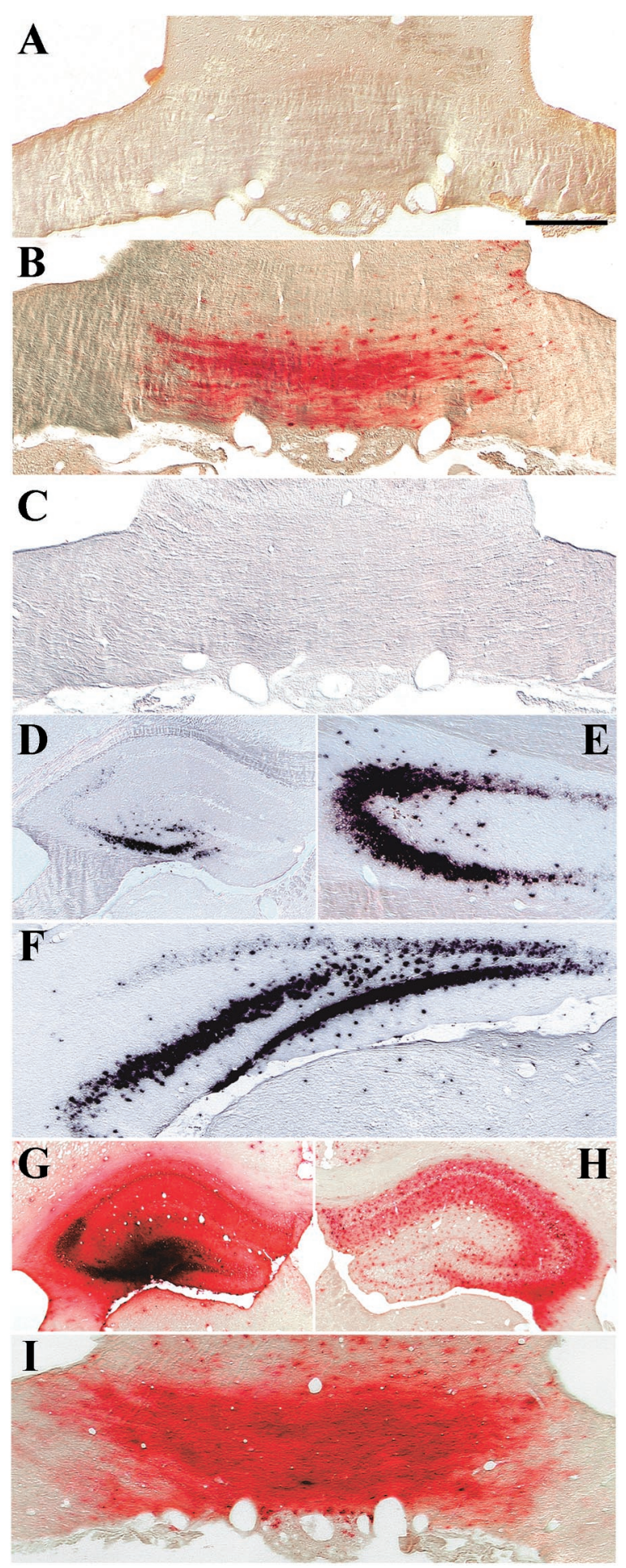

Figure 3. Long-term enzymatic activity and expression in the hippocampal commissure and hippocampus. Shown are enzyme histochemistry $(A$, $B, G-I)$ and ISH-antisense $(C-F)$ in the hippocampal commissure $(A-C$, $I)$, ipsilateral hippocampus $(D-G)$, and contralateral hippocampus $(H)$. Unilateral injections of $\mathrm{AAV} 2-\mathrm{H} \beta \mathrm{H}$ into the ventral hippocampus resulted in undetectable levels of enzyme staining at 1 month PI $(A)$ but detectable levels at 3 months PI $(B)$ in the hippocampal commissure. Although a small number of cell bodies were labeled, the majority of staining was present in a diffuse, linear pattern $(B)$. Vector-encoded human GUSB mRNA was not present in a corresponding section at 3 months $(C)$. Robust transduction was observed in the ventral hippocampus in all three mice at 18 months PI $(D-F)$. In mouse 1 the GUSBexpressing cells were abundant in the CA3 pyramidal cell layer and in the
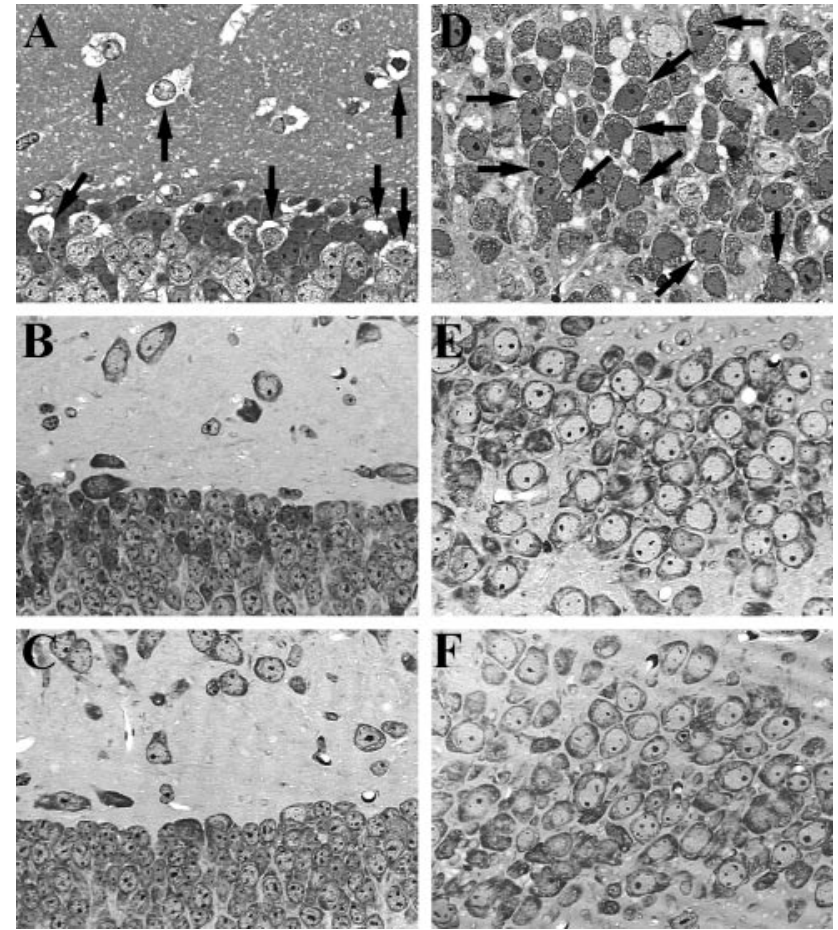

Figure 4. Reversal of pathology in the MPS VII brains after unilateral injection of AAV2-H $\beta \mathrm{H}$ into the ventral hippocampus at 3 months PI. Shown are toluidine blue-stained plastic sections in uninjected $(A, D)$ and injected $(B, C, E, F)$ mice. Lysosomal storage vacuoles were visible in the uninjected GCL and hilus of the dentate gyrus $(A)$ but were cleared in the ipsilateral $(B)$ and contralateral $(C)$ hemispheres of injected brains. Lysosomal storage vacuoles, which were present in the entire CA3 pyramidal cell layer in uninjected mice $(D)$, were reversed in both the ipsilateral $(E)$ and contralateral $(F)$ hemispheres of injected brains. Arrows point to lysosomal storage vacuoles. Scale bar, $50 \mu \mathrm{m}$.

section through the rostral migratory stream, approximately midway between the SVZ and olfactory bulb, showed a high-density chain of enzyme-positive cells that were negative for GUSB mRNA (Fig. 7B,E). A very high number of enzyme-positive cells were observed in the subependymal zone and granule cell layer of the ipsilateral olfactory bulb (Fig. $7 C$ ). However, none of these cells was positive by in situ hybridization (Fig. $7 F$ ). It is unlikely that the lack of expression in the olfactory bulb was attributable to promoter shutdown, because the human GUSB promoter supports transcription in all layers of this structure (Passini and Wolfe, 2001).

Enzymatic activity and gene expression were still present in the SVZ at 18 months (Fig. 7G,J), which resulted in a population of enzyme-positive cells in the granule cell layer of the olfactory bulb (Fig. 7H,I). As with axonal transport, this mode of transport

ventral blade of the dentate GCL $(D)$. In mouse 2 transduced cells were present in the pyramidal layer of CA2 and CA3 $(E)$. In mouse 3 a large number of GUSB-expressing cells were detected in the CA3 pyramidal cell layer and in the GCL and hilus of the dentate gyrus $(F)$. As represented by mouse 1 , widespread enzyme-positive cells were detected in the injected $(G)$ and uninjected $(H)$ hemispheres of all three mice. The most robust enzyme staining in the uninjected hemisphere was detected in CA1-CA3 $(H)$. Other regions, such as the inner molecular layer of the dentate gyrus, were also positive for enzymatic activity $(H)$. A larger area of diffuse enzyme staining was observed in the hippocampal commissure at 18 months $(I)$ compared with 1 month $(A)$ and 3 months $(B)$. Scale bars: $A-D, G, H, 500 \mu \mathrm{m} ; E, F, I, 250 \mu \mathrm{m}$. 
Figure 5. Axonal transport in the nigrostriatal $(A-D)$ and septohippocampal $(E-H)$ systems after AAV2-H $\beta \mathrm{H}$ vector injection. Shown are enzyme histochemistry $(A, C$, $E-G)$ and ISH-antisense $(B, D, H)$. Injections into the striatum resulted in many enzyme- and mRNA-positive cells in this structure at 18 months PI $(A, B)$. Enzymepositive cells were present in the substantia nigra after the striatal injections $(C)$. However, the entire substantia nigra was negative for gene expression $(D)$. After injection of the ventral hippocampus, enzyme-positive cells were undetectable in the septum at 1 month $(E)$ but were detectable at 3 months $(F)$ and 18 months $(G)$. Enzyme-positive cells in the septum were observed in the medial nucleus and in both dorsolateral nuclei, but not in either ventrolateral nucleus $(F, G)$. ISH-antisense did not produce positive cells in the septum at 18 months $(H)$. Scale bars: $A-D, 250 \mu \mathrm{m} ; E-H, 500 \mu \mathrm{m}$.

Figure 6. Correction of storage in the septum after hippocampal injections. Shown are toluidine blue-stained plastic sections of the septum $(A-D)$ and other brain structures $(E-H)$. Storage vacuoles were present in many cells of the uninjected MPS VII medial $(A)$ and lateral $(C)$ septa. Reversal of pathology was observed in neurons and glial cells of the medial $(B)$ and lateral $(D)$ septum 3 months after AAV2-H $\beta \mathrm{H}$ vector injection of the MPS VII ventral hippocampus. These injections did not correct storage lesions in other brain structures, as illustrated by the neocortex $(E)$, piriform cortex $(F)$, caudate putamen $(G)$, and thalamus $(H)$. Arrows point to lysosomal storage vacuoles. Scale bar, $40 \mu \mathrm{m}$.
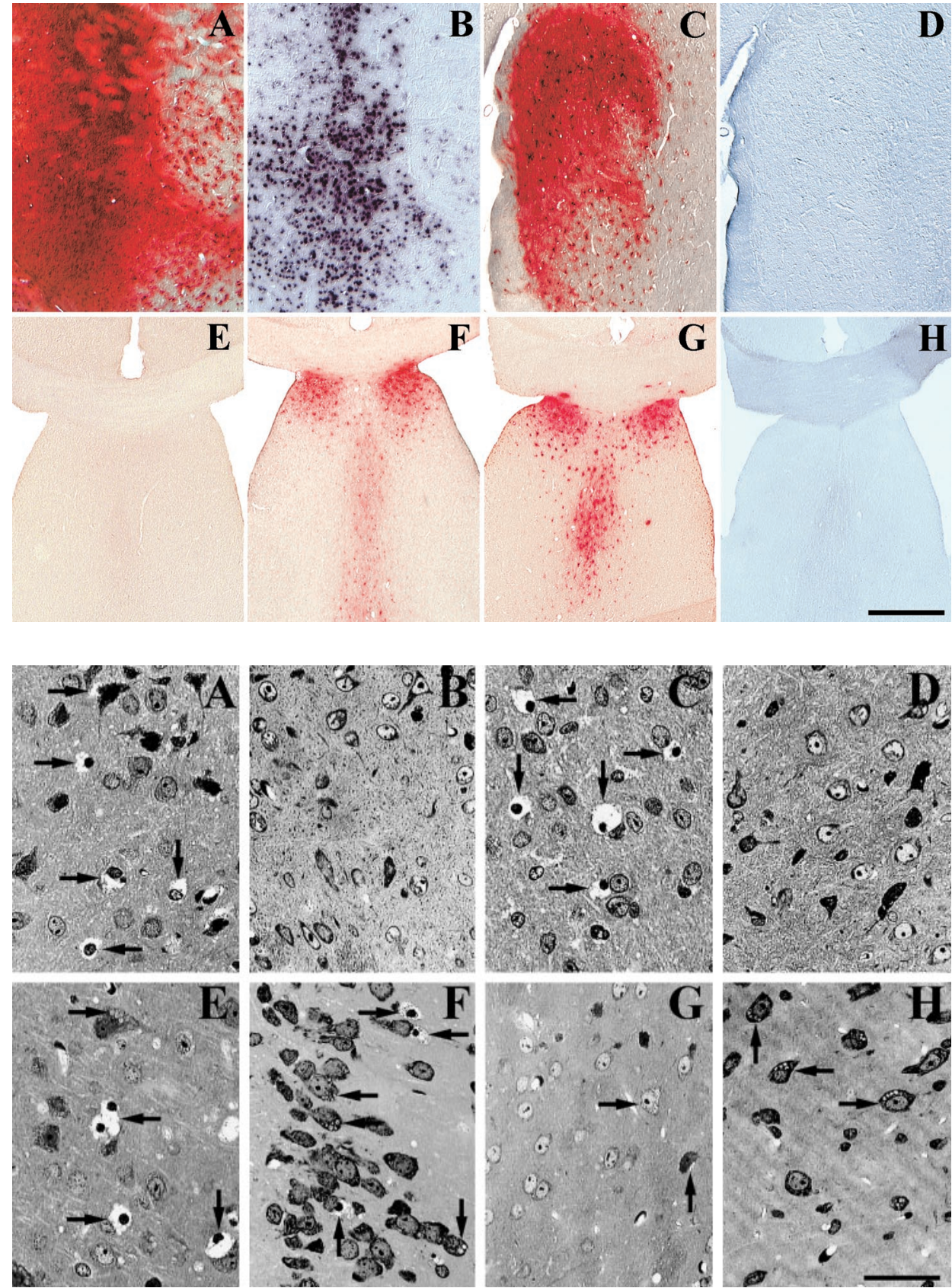

is maintained over time, albeit with less accumulation of enzymatic activity at the distal site. Virally encoded mRNA cells were not detected in the olfactory bulb at 18 months (Fig. $7 K, L$ ).

\section{DISCUSSION}

This study determined the different modes of GUSB transport in the brain with an AAV2 vector regulated by a mammalian housekeeping sequence. The ability of the human GUSB promoter to support gene expression over time is beneficial to experiments that must rely on a continuing source of protein product. The maintenance of GUSB expression in the brain resulted in saturation of enzyme at the injection site and accumulation in distal locations. In contrast, the CMV promoter did not sustain expression over time, consistent with other AAV2 experiments that used viral promoters (Alexander et al., 1996; McCown et al.,
1996; Davidson et al., 2000). Although mammalian regulatory sequences such as the neuronal-specific enolase and plateletderived growth factor promoters support expression in the CNS (Peel et al., 1997; Klein et al., 1998; Xu et al., 2001), the relatively large size of these promoters is a disadvantage when engineering AAV2 recombinant genomes because of size limitations in the packaging reactions (Dong et al., 1996). The minimally sized 378 bp human GUSB promoter thus would provide a distinct advantage in somatic gene transfer experiments involving large cDNAs.

A new finding was the transduction of the adult GCL with both AAV2-H $\beta \mathrm{H}$ and AAV2-CV $\beta$, which had not been seen in previous studies that used AAV2 vectors with either the neuronalspecific enolase or CMV promoters (McCown et al., 1996; Bartlett et al., 1998; Klein et al., 1998; Xu et al., 2001). Interestingly, wild-type AAV2 does not have a natural tropism for the GCL 

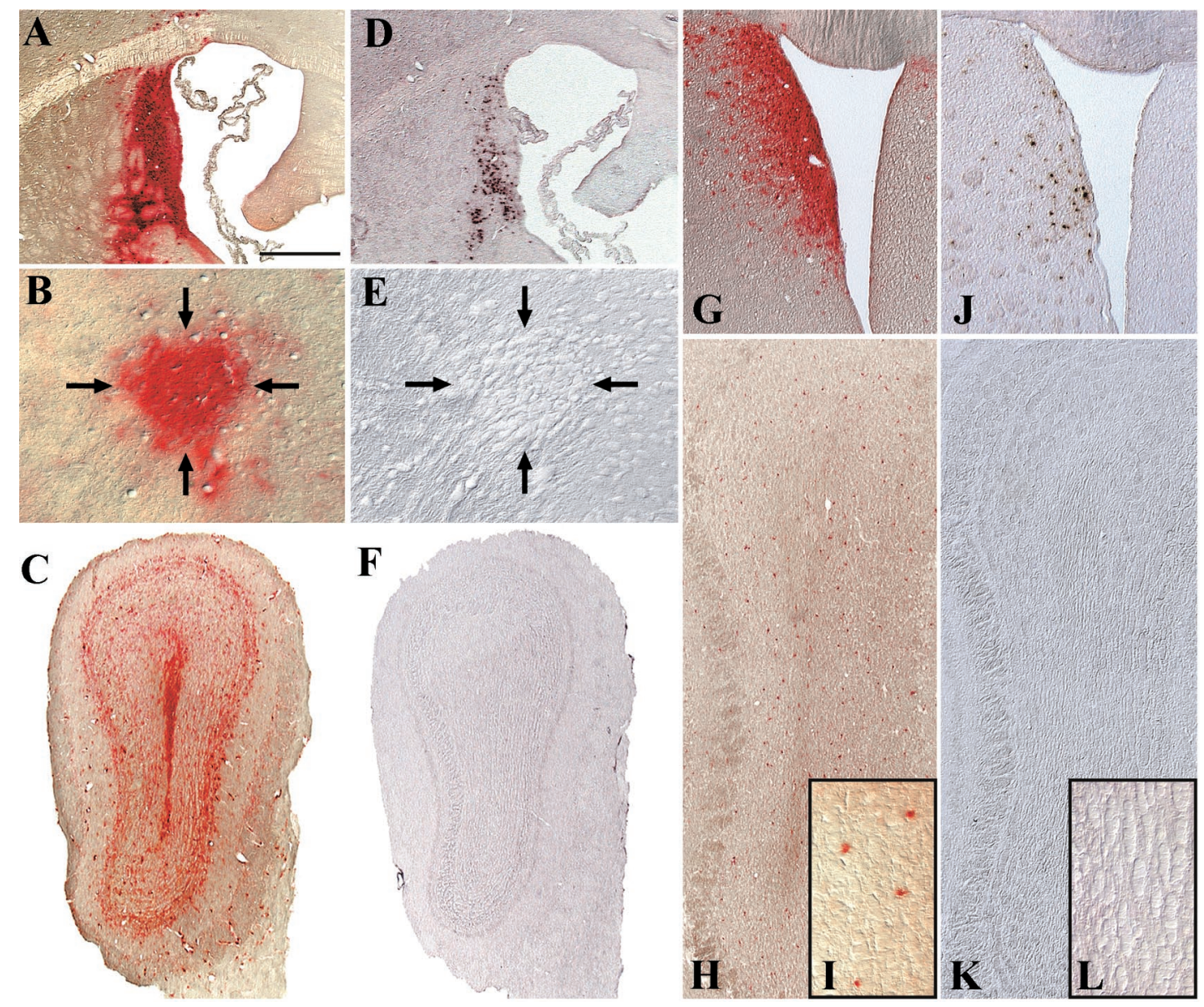

Figure 7. Transport of GUSB in the rostral migratory stream. Shown are enzyme histochemistry $(A-C, G-I)$ and ISH-antisense $(D-F$, $J-L)$ in coronal sections of the subventricular zone $(A, D, G, J)$, the rostral migratory stream $(B, E)$, and the main olfactory bulb $(C, F, H, I, K, L)$ at 1 month PI $(A-F)$ and 18 months PI $(G-L)$. Scale bars: $A, D, 500 \mu \mathrm{m} ; C, F, 400 \mu \mathrm{m} ; G, H, J, K, 250 \mu \mathrm{m} ; B, E, I, L, 60 \mu \mathrm{m}$.

(Bartlett et al., 1998). Our data suggest that the transgene itself may influence the transduction profile of a given AAV2 vector in the brain. This recently was shown to occur with an adenovirus vector, in which different transduction patterns were observed in the brain when different transgenes were used in an identical viral vector backbone (Zermansky et al., 2001). This implies that variegated patterns of transduction will arise in the CNS from unique combinations of promoters and cDNAs.

Our data show that GUSB distribution and reversal of pathology in the contralateral hippocampus are attributable to axonal transport. This is supported by several lines of evidence (Fig. 8). First, the abundant enzyme-positive cells in the contralateral oriens and radiatum layers are explained by the extensive inputs from the commissural axons emanating from CA3 pyramidal neurons (Swanson et al., 1978; Amaral and Witter, 1989). Also, the widespread enzyme pattern in the ipsilateral CA1 field may have occurred via Schaffer collaterals. Second, the presence of enzyme staining in the inner molecular layer of the dentate gyrus is consistent with axonal transport by hilar neurons, because these cells send axons to opposite hemispheres and innervate a laminar position directly adjacent to the GCL (Gottlieb and Cowan, 1973; Swanson and Cowan, 1977). Because the outer molecular layer does not receive input from the dentate gyrus, but rather from the perforant pathways of the entorhinal cortex (Blackstad, 1958; Raisman et al., 1965; Bayer, 1985), it would be predicted that the outer molecular layer would not be positive for GUSB, which is what we have observed (Fig. 2F). In agreement, the lacunosum moleculare layers of CA1-CA3, which were negative for GUSB, also receive input primarily from perforant axons (HjorthSimonsen, 1973; Steward, 1976). Finally, the detection of GUSB in the hippocampal commissure is consistent with the presence of enzyme in the axons.

The enzyme pattern in the septum after hippocampal injections further demonstrates that axonal transport occurred rather than diff usion. GUSB was restricted to the dorsal nucleus of both lateral septa, with no enzyme-positive cells being detected in the ventral nuclei. This pattern is predicted by the topographical organization between the two structures. The rostral-ventral hippocampus (the injected site) innervates the dorsal lateral septum and the caudal-ventral hippocampus innervates the ventral lateral septum (Swanson et al., 1981). If diff usion of GUSB to the septum had occurred, then enzyme-positive cells would have been present in the entire lateral septum, rather than just the dorsal region. Furthermore, structures near the septum and the hippocampus also would have been exposed to any secreted enzyme, but many of these nearby structures were negative for enzyme staining and contained large numbers of cells with storage lesions.

We could not determine unambiguously in which direction GUSB was moving through the circuits of the intrahippocampal and septohippocampal systems. Although neurons in these systems connect in both the retrograde and anterograde directions 

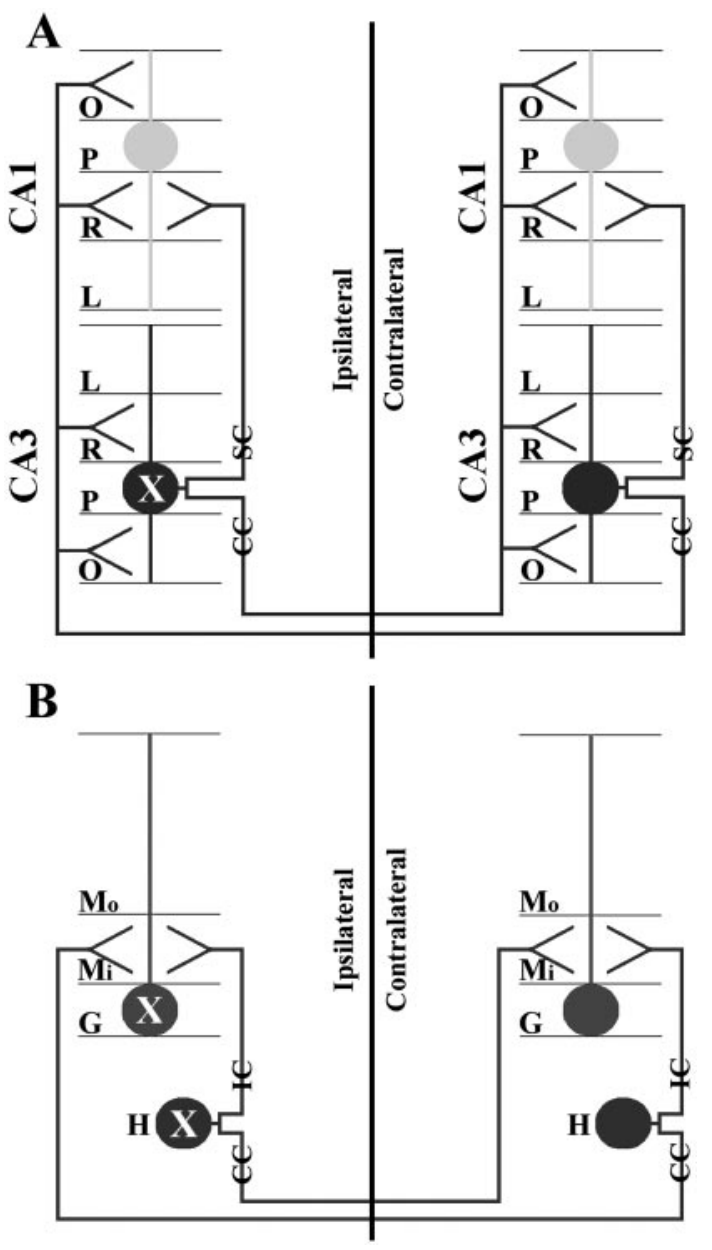

Figure 8. Diagram showing the symmetrical circuitry of the intrahippocampal system. CA1 and CA3 pyramidal cells have dendrites that extend into the oriens, radiatum, and lacunosum layers $(A)$. CA3 pyramidal cells send commissural collaterals to the contralateral CA1-CA3 radiatum and oriens layers and send Schaffer collaterals to the ipsilateral CA1 radiatum layer $(A)$. Dentate granule cells have dendrites that extend into the inner and outer molecular layers $(B)$. Hilar neurons of the dentate gyrus send ipsilateral and commissural collaterals to the inner one-third molecular layer and synapse with dentate granule cells $(B)$. According to these connections the GUSB transport to the contralateral side probably occurred by secretion of GUSB into the ipsilateral synapse by the transduced cell (labeled as $X$ ), followed by uptake by the axonal termini (or terminus) of the contralateral cell and subsequent retrograde transport via the commissural axon to the soma. Although anterograde projections occur, it is not thought that lysosomes move to the synaptic terminus (Walkley, 1998). CC, Commissural collateral; IC, ipsilateral collateral; $P$, pyramidal cell layer; $S C$, Schaffer collateral; see Figure 2 for additional abbreviations.

(Figs. 8, 9), retrograde transport is the most likely explanation for enzyme movement through axons, because endosome trafficking occurs from the synaptic termini to the perikarya in neurons (Nixon and Cataldo, 1995; Overly and Hollenbeck, 1996; Walkley, 1998; Mathews et al., 2002). The correction of storage lesions in neurons distal from the injection site indicates that endosomes carrying GUSB fused with lysosomes after retrograde trafficking in vivo, because the enzyme must reach the acidified lysosome to be active catalytically.

Glial cells surrounding the enzyme-positive distal neurons also were corrected. This indicates that, after the completion of axonal transport, some of the active enzyme was released into the

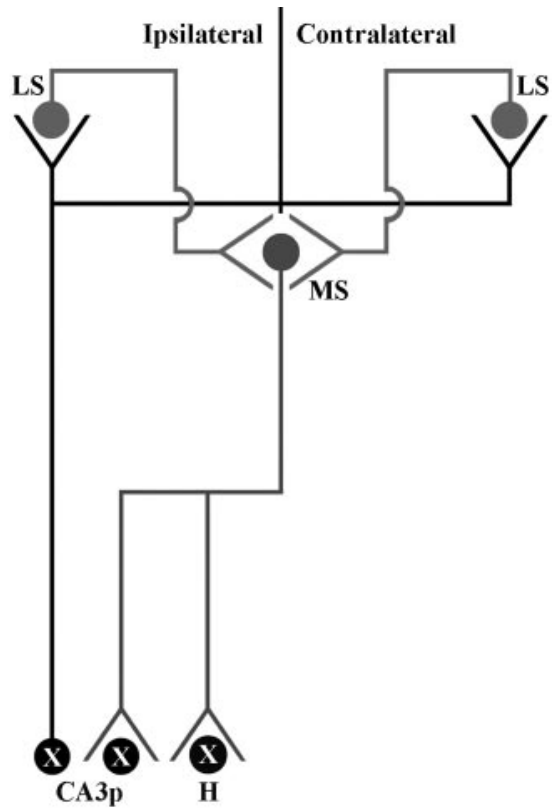

Figure 9. GUSB movement throughout the circuit of the septohippocampal system. Only one hemisphere of the ventral hippocampus is shown. Neurons from the medial septum project onto CA3 pyramidal and dentate hilar cells, whereas CA3 pyramidal cells project onto the lateral septal nuclei of both hemispheres (Swanson, 1977). Retrograde transport in axons of the medial septum is the likely mechanism for GUSB movement in this circuit. Because neurons of the lateral septum also project onto the medial septum, the enzyme pattern and reversal of pathology in the lateral septum probably occur by retrograde transport via a second axon (second-order neuron). CA3p, CA3 pyramidal cell layer; $H$, hilus; $L S$, lateral septum; $M S$, medial septum.

surrounding area and taken up by adjacent cells. This evidence of enzyme in the extracellular space suggests that axon endings in this area also were exposed to secreted enzyme, which would account for the presence of staining in some second-order neurons. This is illustrated by the retrograde transport of GUSB via two connecting neurons in the septohippocampal system (Fig. 9). Although this ability to become transported along multiple neurons can increase the distribution of GUSB in the brain, it was found only in some areas.

Unilateral injections of a lentivirus vector into the fimbria of another mouse model of lysosomal enzyme deficiency (metachromatic leukodystrophy) resulted in reversal of storage lesions in the contralateral CA3 pyramidal cell layer and fimbria (Consiglio et al., 2001). However, because there is no available assay to study the arylsulfatase A enzyme pattern in situ, it could only be conjectured that axonal transport was responsible for enzyme movement throughout the hippocampus. Those data together with the present study suggest that axonal transport may be a general property of lysosomal enzymes.

GUSB also was transferred long distances by migrating cells. Injection of AAV2-H $\beta \mathrm{H}$ into the vicinity of the SVZ resulted in enzyme-positive cells in the olfactory bulb. However, there was no gene expression detected by in situ hybridization in the rostral migratory stream or olfactory bulb, indicating that the vector did not transduce the stem cell population leaving the SVZ. Rather, transduced cells in the vicinity of the SVZ secreted GUSB, which then was taken up by cells entering the rostral migratory stream. The GUSB half-life of 3-6 d (Achord et al., 1977; Vogler et al., 1993) allows a significant amount of enzyme to survive the jour- 
ney to the olfactory bulb, because the time it takes for SVZ cells to travel down the rostral migratory is also 3-6 d (Luskin, 1993). The lack of stem cell infection with AAV2 differs from SVZ injections with retrovirus and adenovirus, which resulted in stem cell transduction and subsequent delivery of the $\beta$-galactosidase reporter gene to the granule and periglomerular cell layers (Luskin, 1993; Yoon et al., 1996).

In contrast to the SVZ, the maintenance of gene expression for at least 18 months in the GCL suggests that AAV2-H $\beta \mathrm{H}$ infected stem cells of the dentate gyrus, which continuously supply new granule cells to replace dying ones (Kaplan and Hinds, 1977; Bayer, 1982; Gage, 2000). This differed from our recent finding with AAV2-H $\beta \mathrm{H}$ injections in the developing brain (Passini and Wolfe, 2001), which resulted in a continual decrease in the number of in situ hybridization-positive cells over time in the GCL, indicating that stem cells of the dentate gyrus were not infected at birth. The combined data from both studies suggest that AAV2 vectors are permissive for the infection of some pools of stem cells, but not of others, and that transduction of a given stem cell population can differ between a developing and mature brain.

In conclusion, we determined that there are alternate ways in which lysosomal enzymes can become distributed throughout the brain. The transport occurred for at least 18 months, demonstrating that strategically placed enzyme-secreting foci can provide a long-term supply of enzyme to locations far away from the injection site by diffusion, axonal transport, and migrating crosscorrected cells. The use of all three modes of transport in treatment strategies should be beneficial in reversing the global neuropathology of lysosomal storage diseases in future clinical trials.

\section{REFERENCES}

Achord D, Brot F, Gonzalez-Noriega A, Sly W, Stahl P (1977) Human $\beta$-glucuronidase. II. Fate of infused human placental $\beta$-glucuronidase in the rat. Pediatr Res 11:816-822.

Alexander IE, Russell DW, Spence AM, Miller AD (1996) Effects of gamma irradiation on the transduction of dividing and nondividing cells in brain and muscle of rats by adeno-associated virus vectors. Hum Gene Ther 7:841-850.

Altman J (1969) Autoradiographic and histological studies of postnatal neurogenesis. IV. Cell proliferation and migration in the anterior forebrain, with special reference to persisting neurogenesis in the olfactory bulb. J Comp Neurol 137:433-457.

Amaral DG, Witter MP (1989) The three-dimensional organization of the hippocampal formation: a review of anatomical data. Neuroscience 31:571-591.

Barthel LK, Raymond PA (2000) In situ hybridization studies of retinal neurons. Methods Enzymol 316:579-590.

Bartlett JS, Samulski RJ, McCown TJ (1998) Selective and rapid uptake of adeno-associated virus type 2 in brain. Hum Gene Ther 9:1181-1186.

Bayer SA (1982) Changes in the total number of dentate granule cells in juvenile and adult rats: a correlation volumetric and ${ }^{3} \mathrm{H}$-thymidine autoradiographic study. Exp Brain Res 46:315-323.

Bayer SA (1985) Forebrain and midbrain. In: The rat nervous system, Vol I (Paxinos G, ed), pp 335-352. San Diego: Academic.

Birkenmeier EH, Davisson MT, Bearner WG, Ganschow RE, Vogler CA, Gwynn B, Lyford KA, Maltais LM, Wawrzyniak CJ (1989) Murine mucopolysaccharidosis VII: characterization of a mouse with $\beta$-glucuronidase deficiency. J Clin Invest 83:1258-1266.

Blackstad TW (1958) On the termination of some afferents to the hippocampus and fascia dentate. An experimental study in the rat. Acta Anat 35:202-214.

Bosch A, Perret E, Desmaris N, Heard JM (2000a) Long-term and significant correction of brain lesions in adult mucopolysaccharidosis type VII mice using recombinant AAV vectors. Mol Ther 1:63-70.

Bosch A, Perret E, Desmaris N, Trono D, Heard JM (2000b) Reversal of pathology in the entire brain of mucopolysaccharidosis type VII mice after lentiviral-mediated gene transfer. Hum Gene Ther 11:1139-1150.

Casal ML, Wolfe JH (1998) Variant clinical course of mucopolysaccharidosis type VII in two groups of mice carrying the same mutation. Lab Invest 78:1575-1581.
Casal ML, Wolfe JH (2001) In utero transplantation of fetal liver cells in the mucopolysaccharidosis type VII mouse results in low-level chimerism, but overexpression of $\beta$-glucuronidase can delay onset of clinical signs. Blood 97:1625-1634.

Chamberlin NL, Du B, de Lacalle S, Saper CB (1998) Recombinant adeno-associated virus vector: use for transgene expression and anterograde tract tracing in the CNS. Brain Res 793:169-175.

Consiglio A, Quattrini A, Martino S, Bensadoun JC, Dolcetta D, Trojani A, Benaglia G, Marchesini S, Cestari V, Oliverio A, Bordignon C, Naldini L (2001) In vivo gene therapy of metachromatic leukodystrophy by lentiviral vectors: correction of neuropathology and protection against learning impairments in affected mice. Nat Med 7:310-316.

Davidson BL, Stein CS, Heth JA, Martins I, Kotin RM, Derksen TA, Zabner J, Ghodsi A, Chiorini JA (2000) Recombinant adenoassociated virus type 2, 4, and 5 vectors: transduction of various cell types and regions in the mamalian CNS. Proc Natl Aca Sci USA 97:3428-3432.

Dong JY, Fan PD, Frizzell RA (1996) Quantitative analysis of the packaging capacity of recombinant AAV. Hum Gene Ther 7:2101-2112.

Fisher KJ, Jooss K, Alston J, Yang Y, Haecker SE, High K, Pathak R, Raper SE, Wilson JM (1997) Recombinant adeno-associated virus for muscle-directed gene therapy. Nat Med 3:306-312.

Frankel HA, Glaser JH, Sly WS (1977) Human $\beta$-glucuronidase. I. Recognition and uptake by animal fibroblasts suggest animal models for enzyme replacement studies. Pediatr Res 11:811-816.

Franklin KBJ, Paxinos G (1997) The mouse brain in stereotaxic coordinates. San Diego: Academic.

Frisella WA, O’Connor LH, Vogler CA, Roberts M, Walkley S, Levy B, Daly TM, Sands MS (2001) Intracranial injection of recombinant adeno-associated virus improves cognitive function in a murine model of mucopolysaccharidosis type VII. Mol Ther 3:351-358.

Gage FH (2000) Mammalian neural stem cells. Science 287:1433-1438.

Gallagher PM, D'Amore MA, Lund SD, Elliott RW, Pazik J, Hohman C, Korfhagen TR, Ganschow RE (1987) DNA sequence variation within the $\beta$-glucuronidase gene complex among inbred strains of mice. Genomics 1:145-152.

Ghodsi A, Stein C, Derksen T, Yang G, Anderson RD, Davidson BL (1998) Extensive $\beta$-glucuronidase activity in murine central nervous system after adenovirus-mediated gene transfer to the brain. Hum Gene Ther 9:2331-2340.

Gottlieb DI, Cowan WM (1973) Autoradiographic studies of the commissural and ipsilateral association connections of the hippocampus and dentate gyrus of the rat. I. The commissural connections. J Comp Neurol 149:393-422.

Hjorth-Simonsen A (1973) Some intrinsic connections of the hippocampus in the rat: an experimental analysis. J Comp Neurol 147:145-162.

Johnson WG, Hong JL, Knights SM (1986) Variations in ten lysosomal hydrolase enzyme activities in inbred mouse strains. Biochem Genet 24:891-909.

Kaplan MS, Hinds JW (1977) Neurogenesis in the adult rat: electron microscopic analysis of light radioautographs. Science 197:1092-1094.

Kaplitt MG, Leone P, Samulski RJ, Xiao X, Pfaff DW, O’Malley KL, During MJ (1994) Long-term gene expression and phenotypic correction using adeno-associated virus vectors in the mammalian brain. Nat Genet 8:148-154.

Klein RL, Meyer EM, Peel AL, Zolotukhin S, Meyers C, Muzyczka N, King MA (1998) Neuron-specific transduction in the rat septohippocampal or nigrostriatal pathway by recombinant adeno-associated virus vector. Exp Neurol 150:183-194.

Klein RL, Mandal RJ, Muzyczka N (2000) Adeno-associated virus vector-mediated gene transfer to somatic cells in the central nervous system. Adv Virus Res 55:507-528.

Kordower JH, Emborg ME, Bloch J, Ma SY, Chu Y, Leventhal L, McBride J, Chen EY, Palfi S, Roitberg BZ, Brown WD, Holden JE, Pyzalski R, Taylor MD, Carvey P, Ling Z, Trono D, Hantraye P, Deglon N, Aebischer P (2000) Neurodegeneration prevented by lentiviral delivery of GDNF in primate models of Parkinson's disease. Science 290:767-773.

Kyle JW, Birkenmeier EH, Gwynn B, Vogler C, Hoppe PC, Hoffmann JW, Sly WS (1990) Correction of murine mucopolysaccharidosis VII by a human $\beta$-glucuronidase transgene. Proc Natl Acad Sci USA 81:6466-6470.

Levy B, Galvin N, Vogler C, Birkenmeier EH, Sly WS (1996) Neuropathology of murine mucopolysaccharidosis type V II. Acta Neuropathol (Berl) 92:562-568.

Lois C, Alvarez-Buylla A (1994) Long-distance neuronal migration in the adult mammalian brain. Science 264:1145-1148.

Luskin MB (1993) Restricted proliferation and migration of postnatally generated neurons derived from the forebrain subventricular zone. Neuron 11:173-189.

Mathews PM, Guerra CB, Jiang Y, Grbovic OM, Kao BH, Schmidt SD, Dinakar R, Mercken M, Hille-Rehfeld A, Rohrer J, Mehta P, Cataldo AM, Nixon RA (2002) Alzheimer's disease-related overexpression of the cation-dependent mannose 6-phosphate receptor increases $\mathrm{A} \beta$ se- 
cretion: role for altered lysosomal hydrolase distribution in $\beta$-amyloidogenesis. J Biol Chem 277:5299-5307.

McCown TJ, Xiao X, Li J, Breese GR, Samulski RJ (1996) Differential and persistent expression patterns of CNS gene transfer by an adenoassociated virus (AAV) vector. Brain Res 713:99-107.

Miller RD, Hoffman JW, Powell PP, Kyle JW, Shipley JM, Bachinsky DR, Sly WS (1990) Cloning and characterization of the human $\beta$-glucuronidase gene. Genomics 7:280-283.

Moullier P, Bohl D, Heard JM, Danos O (1993) Correction of lysosomal storage in the liver and spleen of MPS VII mice by implantation of genetically modified skin fibroblasts. Nat Genet 4:154-159.

Neufeld EF (1991) Lysosomal disease. Annu Rev Biochem 60:257-280.

Neufeld EF, Fratantoni JC (1970) Inborn errors of mucopolysaccharide metabolism. Science 169:141-146.

Nixon RA, Cataldo AM (1995) The endosomal-lysosomal system of neurons: new roles. Trends Neurosci 18:489-496.

Olsen I, Dean MF, Harris G, Muir H (1981) Direct transfer of a lysosomal enzyme from lymphoid cells to deficient fibroblasts. Nature 291:244-247.

Oshima A, Kyle JW, Miller RD, Hoffmann JW, Powell PP, Grubb JH, Sly WS, Tropak M, Guise KS, Gravel RA (1987) Cloning, sequencing, and expression of cDNA for human $\beta$-glucuronidase. Proc Natl Acad Sci USA 84:685-689.

Overly CC, Hollenbeck PJ (1996) Dynamic organization of endocytic pathways in axons of cultured sympathetic neurons. $J$ Neurosci 16:6056-6064.

Passini MA, Wolfe JH (2001) Widespread gene delivery and structurespecific patterns of expression in the brain from an adeno-associated virus vector following intraventricular injections of neonatal mice. J Virol 75:12382-12392

Peel AL, Zolotukhin S, Schrimsher GW, Muzyczka N, Reier PJ (1997) Efficient transduction of green fluorescent protein in spinal cord neurons using adeno-associated virus vectors containing cell type-specific promoters. Gene Ther 4:16-24.

Peltekian E, Garcia L, Danos O (2002) Neurotropism and retrograde axonal transport of a canine adenoviral vector: a tool for targeting key structures undergoing neurodegenerative processes. Mol Ther 5:25-32.

Raisman G, Cowan WM, Powell TPS (1965) The extrinsic afferent, commissural, and association fibers of the hippocampus. Brain 88:963-996.

Sando GN, Neufeld EF (1977) Recognition and receptor-mediated uptake of a lysosomal enzyme, $\alpha$-L-iduronidase, by cultured human fibroblasts. Cell 12:619-627.

Sands MS, Birkenmeier EH (1993) A single-base-pair deletion in the $\beta$-glucuronidase gene accounts for the phenotype of murine mucopolysaccharidosis type VII. Proc Natl Acad Sci USA 90:6567-6571.

Serguera C, Sarkis C, Ridet JL, Colin P, Moullier P, Mallet J (2001) Primary adult human astrocytes as an ex vivo vehicle for $\beta$-glucuronidase delivery in the brain. Mol Ther 3:875-881.

Sferra TJ, Qu G, McNeely D, Rennard R, Clark KR, Lo WD, Johnson PR (2000) Recombinant adeno-associated virus-mediated correction of lysosomal storage within the central nervous system of the adult mucopolysaccharidosis type VII mouse. Hum Gene Ther 11:507-519.

Shipley JM, Miller RD, Wu BM, Grubb JH, Christensen SG, Kyle JW, Sly WS (1991) Analysis of the 5' flanking region of the human $\beta$-glucuronidase gene. Genomics 10:1009-1018.

Skorupa AF, Fisher KJ, Wilson JM, Parente MK, Wolfe JH (1999) Sustained production of $\beta$-glucuronidase from localized sites after AAV vector gene transfer results in widespread distribution of enzyme and reversal of lysosomal storage lesions in a large volume of brain in mucopolysaccharidosis VII mice. Exp Neurol 160:17-27.

Snyder EY, Taylor RM, Wolfe JH (1995) Neural progenitor cell engraftment corrects lysosomal storage throughout the MPS VII mouse brain. Nature 374:367-370.
Stein CS, Ghodsi A, Derksen T, Davidson BL (1999) Systemic and central nervous system correction of lysosomal storage in mucopolysaccharidosis type VII mice. J Virol 73:3424-3429.

Steward O (1976) Topographic organization of projections from the entorhinal area to the hippocampal formation of the rat. J Comp Neurol 167:285-314.

Swanson LW (1977) The anatomical organization of septohippocampal projections. Ciba Found Symp 58:25-48.

Swanson LW, Cowan WM (1977) An autoradiographic study of the organization of the efferent connections of the hippocampal formation in the rat. J Comp Neurol 172:49-84.

Swanson LW, Wyss JM, Cowan WM (1978) An autoradiographic study of the organization of intrahippocampal association pathways in the rat. J Comp Neurol 181:681-716.

Swanson LW, Sawchenko PE, Cowan WM (1981) Evidence for collateral projections by neurons in Ammon's horn, the dentate gyrus, and the subiculum: a multiple retrograde labeling study in the rat. J Neurosci 1:548-559.

Taylor RM, Wolfe JH (1994) Cross-correction of $\beta$-glucuronidase deficiency by retroviral vector-mediated gene transfer. Exp Cell Res 214:606-613

Taylor RM, Wolfe JH (1997) Decreased lysosomal storage in the adult MPS VII mouse brain in the vicinity of grafts of retroviral vectorcorrected fibroblasts secreting high levels of $\beta$-glucuronidase. Nat Med 3:771-774.

Uchida N, Buck DW, He D, Reitsma MJ, Masek M, Phan TV, Tsukamoto AS, Gage FG, Weissman IL (2000) Direct isolation of human central nervous system stem cells. Proc Natl Acad Sci USA 97:14720-14725.

Vogler C, Birkenmeier EH, Sly WS, Levy B, Pegors C, Kyle JW, Beamer WG (1990) A murine model of mucopolysaccharidosis VII. Am J Pathol 136:207-217.

Vogler C, Sands M, Higgins A, Levy B, Grubb J, Birkenmeier EH, Sly WS (1993) Enzyme replacement with recombinant $\beta$-glucuronidase in the newborn mucopolysaccharidosis type VII mouse. Pediatr Res 34:837-840.

Walkley SU (1998) Cellular pathology of lysosomal storage disorders. Brain Pathol 8:175-193.

Wolfe JH, Sands MS (1996) Murine mucopolysaccharidosis type VII: a model for somatic gene therapy of the central nervous system. In: Protocols for gene transfer in neuroscience: towards gene therapy of neurological disorders (Lowenstein PR, Enquist LW, eds), pp 263-274. London: Wiley.

Wolfe JH, Kyle JW, Sands MS, Sly WS, Markowitz DG, Parente MK (1995) High level expression and export of $\beta$-glucuronidase from murine mucopolysaccharidosis VII cells corrected by a double-copy retrovirus vector. Gene Ther 2:70-78.

$\mathrm{Xu}$ R, Janson CG, Mastakov M, Lawlor P, Young D, Mouravlev A, Fitzsimons H, Choi KL, Ma H, Dragunow M, Leone P, Chen Q, Dicker B, During MJ (2001) Quantitative comparison of expression with adeno-associated virus (AAV-2) brain-specific gene cassettes. Gene Ther 8:1323-1332.

Yoon SO, Lois C, Alvirez M, Alvarez-Buylla A, Falck-Pedersen E, Chao MV (1996) Adenovirus-mediated gene delivery into neuronal precursors of adult mouse brain. Proc Natl Acad Sci USA 93:11974-11979.

Zermansky AJ, Bolognani F, Stone D, Cowsill CM, Morrissey G, Castro MG, Lowenstein PR (2001) Towards global and long-term neurological gene therapy: unexpected transgene-dependent, high-level, and widespread distribution of HSV-1 thymidine kinase throughout the CNS. Mol Ther 4:490-498.

Zhu J, Kang W, Wolfe JH, Frasier NW (2000) Significantly increased expression of $\beta$-glucuronidase in the central nervous system of mucopolysaccharidosis type VII mice from the latency-associated transcript promoter in a nonpathogenic herpes simplex virus type 1 vector. Mol Ther 2:82-94. 